\title{
SOLUTIONS FOR ENVIRONMENTAL CONTRASTS IN COASTAL AREAS (SECOA): COASTAL CITIES AND CLIMATE CHANGE
}

\author{
Professor Graeme Evans (Graeme.Evans@brunel.ac.uk)
}

\section{Introduction}

Coastal cities and regions are a particular focus in the $21^{\text {st }}$ century. Over two thirds of the top 25 megacities are coastal, with housing and land use intensification increasingly taking place in city extensions and growth zones in areas of 'high risk' flood plain and sea level rise. In the past decade alone the effects of tsunamis, earthquakes, hurricanes and floods have been felt in many countries, both tropical and temperate. Coastal cities are thus at a convergence point for two complex ecosystems: the natural ecosystem of the coastal zone, and the constructed ecosystem of concentrated human settlement. There has been extensive work over the past 25 years in both the management and planning urban areas, and in coastal management. However there has been little research or integrated policy and planning specifically linking these two into what can be identified as 'coastal cities' research (Timmerman 1996). The SECOA project - presented at the Regional Studies Regions \& Environment conference (see REGIONS No.281) - is working in response to this challenge to develop integrated solutions for coastal city planning, management and conflict resolution (www.projectsecoa.eu).

\section{Integrated Coastal Zone Management (ICZM)}

ICZM is the holy grail of sustainable coastal protection and development. From 1969 the EU ran a demonstration programme on ICZM with 35 projects and 6 thematic studies. This provided technical information on sustainable coastal zone management and stimulated a debate among various actors involved in the planning, management or use of coastal zones. In 2000 the EU adopted 'Integrated Coastal Zone Management: A Strategy for Europe' with a number of measures including establishing progress indicators and data in 2002. During 2006/7 the EU reviewed the experience to date in ICZM and invited coastal member states to develop national strategies. From the ICZM national evaluation survey, participating countries felt that new laws, regulations and/or policies were still required to regulate and manage coastal zones (notably in Belgium and UK) and most disagreed or were uncertain that participatory methods and stakeholder interests were incorporated in national ICZM strategies. At that time, no EU countries had fully implemented national ICZM strategies, whilst some such as Italy and Sweden only had fragmented tools in place. Climate change 'science' discourses (and controversies) provide little practical guidance to the local practitioner or politician, or accessible advice for residents or developers. Early examples of community consultation in Portsmouth's harbour redevelopment for instance, engaged only a handful of residents and only a very small group of vested interest groups (Edwards et al, 1997).

A key research and knowledge exchange intervention in this field has been the EU's INTERREG programme under the regional development fund (ERDF) - collaborations between universities and local and regional authorities and agencies, and other end-user partners (e.g. Coastal Communities, Environmental NGOs). Examples since 2000 include FLOOD-WISE, FloodResilienCity and COMCOAST. It is notable that the majority of these projects have been led by Dutch organisations, confirming their long established experience in water and flood engineering. Eastern and Baltic states have been particularly active, again a reflection of their vulnerability, under-investment in flood/sea defences and major incidences with catastrophic floods along the Danube and Elbe rivers in 2002. 
Between 1998 and 2004, Europe suffered over major 100 damaging floods with severe floods in 2005 reinforcing the need for concerted action. In London, the Thames Barrier has had to be closed over 100 times to protect the city from flooding - both tidal surges and rainfall/river flooding, whilst land designated for development in the Thames Gateway is situated in flood risk areas - with 13 out of 14 zones within the Thames tidal floodplain and therefore vulnerable to both storm surges and peak river flows.

Climate change and associated risks and hazards from flooding therefore represent an increasing threat for urban and coastal communities including areas undergoing urban growth and densification. In the UK for instance since 2006 planning policy has strengthened regulatory powers with the statutory requirement to consult the Environment Agency (EA) on planning proposals in flood risk areas and sites (PPS 25 Development \& Flood Risk). Following the Pitt review of the UK summer floods in 2007, local authorities became the key organisation for surface water flooding alongside their planning, environmental health and land use development roles. This called for improved modelling of combined forms of flooding and highlighted the need for sustainable drainage systems (SuDs) and Surface Water Management Plans (SWMP) as key elements of the planning process. In Making Space for Water (EA 2003) the UK Government reviewed flood and coastal erosion risk management policy in the light of the latest predictions on climate change, land development and evidence that more needed to be done to ensure the adoption of national strategic priorities. This placed greater emphasis on flood risk management and the use of land and spatial planning (including managed realignment) as alternatives to traditional flood defence. As such PP25 forms the basis of the national policy on flooding and development. This should inform regional planning bodies in preparing Regional Spatial Strategies (RSS), Catchment Flood Risk Management Plans (CFMPs) and Local Planning Authorities in developing Local Development Frameworks (LDFs). PPS 25 also requires local authorities to produce Strategic Flood Risk Assessments (SFRAs). Regional Spatial Strategies were identified as the primary mechanism for taking forward recommendations from both Making Space for Water, PPS 25 and in the Pitt Report. However, with the demise of the regional development agencies (RDAs) in England and the dismantling of regional planning and RSS, this implementation looks uncertain. The responsibility for coastal defence strategies, shoreline management plans and investment also looks to the local including the development process (e.g. planning gain, Community Infrastructure Levy) - but this is against a backdrop of public spending restriction and reductions at national and local levels. Furthermore, privatisation of water utilities has left crucial information on water and sewage infrastructure and flood incidents fragmented and even subject to 'commercial confidentiality'. Integration of coastal and flood risk prevention is therefore only achievable if there is transparency and regional level coordination.

In 2007 the EU Flood Directive on the assessment and management of flood risks was enacted. This Directive requires Member States to assess if all water courses and coast lines are at risk from flooding, to map the flood extent and assets and humans at risk and to take adequate and coordinated measures to reduce this risk. The Directive also reinforces the rights of the public to access this information and have a say in the planning process. For the first time this strategy applies to inland as well as coastal waters across the whole territory of the EU. This thus seeks to bridge the artificial divide between coastal and fluvial flood risk and management, particularly urban Estuary areas (e.g. Thames Gateway), and water amenity and infrastructure, particularly with the pressures 
on development, carrying capacity and surface water, drainage and pollution risks. This integration also allows the wider city and coastal areas to be assessed and planned at regional scale, recognising that the core, ring and coastal strips are part of an interconnected whole, driven by mobility and urban development arising from population growth, land use densification, travel to work, tourism and resultant 'coastal squeeze' and waterfront (re)development.

\section{SECOA}

SECOA has been designed to work at this city-coast regional scale, and to draw on experience, conflicts and resilience developed in Europe and uniquely also in Southern regions. The geographic spread of university and end-user partners therefore encompasses northern (UK, Sweden, Belgium), and southern Europe (Portugal, Italy) and the 'South' (Israel, India and Vietnam) - Figure $1 \& 2$. Together these reflect not just differing geographies, climate and ecosystems, but European and non-European land use planning, governance, political and social-cultural systems and histories. Mumbai's flood's in 2005 where nearly a meter of rain fell in just one day also influenced the Commission's decision to bring together European with Southern partners. The comparative regional and environmental policies and practices will provide a research base and a common knowledge platform - using GIS spatial data - which is assessing the extent to which integrated coastal zone management (ICZM) operates, and how far convergence is demonstrated towards EU directives using good practice.

Figure 1. SECOA National Case Study Areas

\begin{tabular}{|l|l|l|}
\hline Country & Case study 1 & Case study 2 \\
\hline Italy & $\begin{array}{l}\text { Rome Metropolitan Area } \\
\text { (Tyrrhenian Sea) }\end{array}$ & $\begin{array}{l}\text { Chieti-Pescara urban area } \\
\text { (Adriatic Sea) }\end{array}$ \\
\hline Belgium & Oostende & Zeebrugge \\
\hline Portugal & Lisbon Metropolitan Area & Algarve Region and Funchal urban area \\
\hline UK & Thames Gateway & Portsmouth city \\
\hline Israel & Tel Aviv metropolitan area & Haifa metropolitan area \\
\hline India & $\begin{array}{l}\text { Mumbai (Bombay) Metropolitan } \\
\text { Area }\end{array}$ & Chennai (Madras) Metropolitan Area \\
\hline Vietnam & Hai Phong & Nha Trang \\
\hline Sweden & Gothenburg Metropolitan Area & Malmo Metropolitan Area \\
\hline
\end{tabular}


Figure 2. Map of SECOA case studies

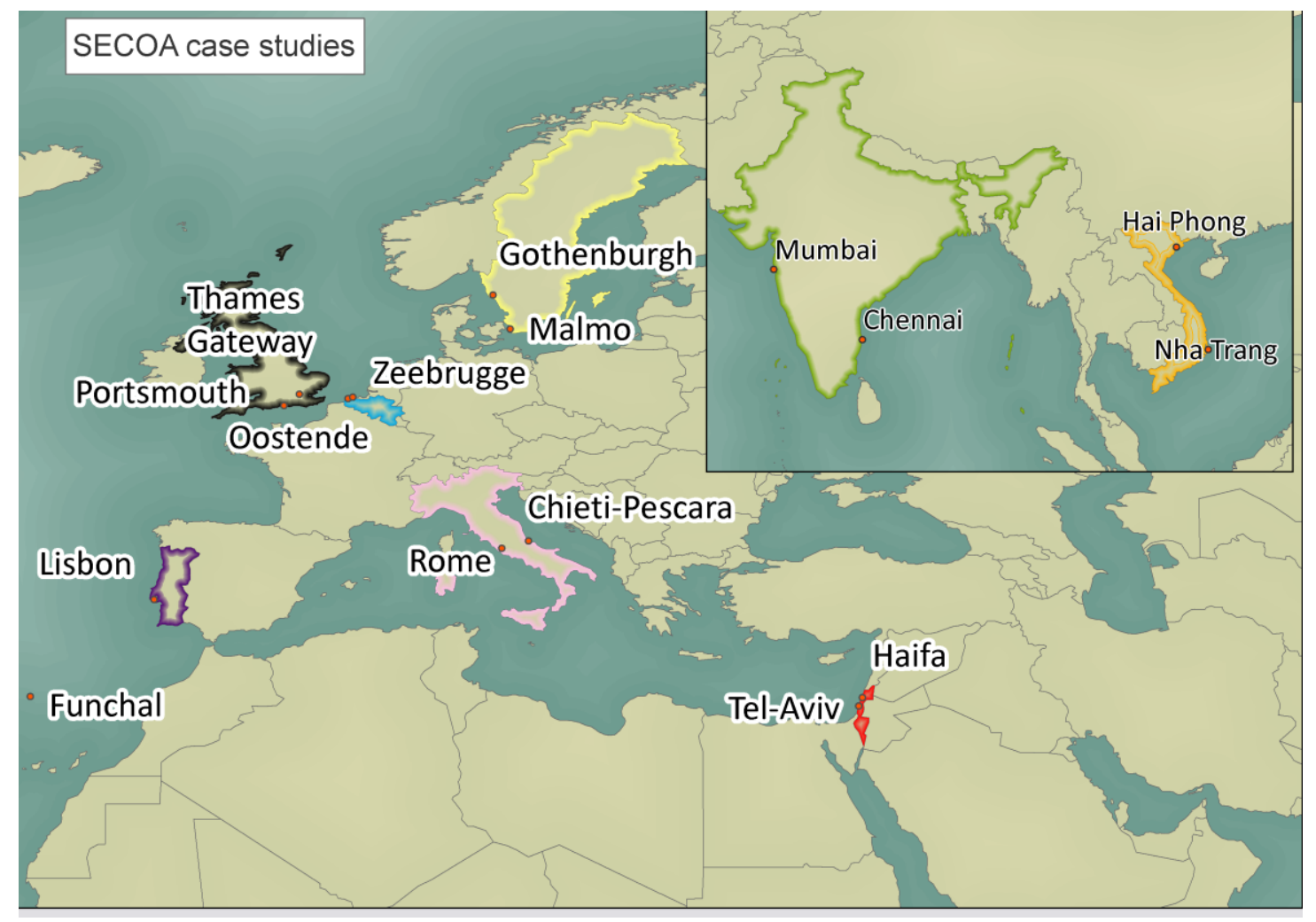

SECOA has so far undertaken a major baseline data and contextual analysis of the case study regions and coastal areas in terms of climate change and natural hazards, environmental stresses and resources, as well as socio-economic and cultural profiles, including human mobility, land use and population change and forecasts. This has produced a major database and comparative framework between the coastal regions. From this assessment, a number of conflict areas have been selected in consultation with local and regional agencies and communities (Fig.3).

In order to create a representative spread of case studies, categories of uses cover ports \& harbours $(\mathrm{PH})$, urban growth development (UGD) areas including tourism, and natural environment habitats (NEH), such as parks, beaches and natural areas. Within these land/resource uses, three conflict themes were identified in each coastal region: Economic development and environmental protection; Preservation of natural sites and biodiversity; and Human mobility and resource use. Fieldwork with local users, communities, planners and developers has captured the conflict process using network analysis, GIS-Participation and other survey techniques. 
Figure 3. Coastal Conflict Case Studies

\begin{tabular}{|c|c|}
\hline Case & Location \\
\hline 1. Civitavecchia & $\begin{array}{l}\text { Rome Metropolitan } \\
\text { Area }\end{array}$ \\
\hline $\begin{array}{l}\text { 2. The "Costa Teatina" } \\
\text { National Park }\end{array}$ & $\begin{array}{l}\text { Chieti-Pescara } \\
\text { urban area }\end{array}$ \\
\hline $\begin{array}{l}\text { 3. Ostia water-use \& } \\
\text { management }\end{array}$ & $\begin{array}{l}\text { Rome Metropolitan } \\
\text { Area }\end{array}$ \\
\hline 4. Ostend airport & Ostend \\
\hline 5. Schipdonk canal & Zeebrugge-Ghent \\
\hline 6. Zeebrugge harbour & Zeebrugge \\
\hline $\begin{array}{l}\text { 7. Trafaria and Costa da } \\
\text { Caparica, }\end{array}$ & $\begin{array}{l}\text { Lisbon } \\
\text { Metropolitan Area }\end{array}$ \\
\hline $\begin{array}{l}\text { 8. Barrier islands [Ria } \\
\text { Formosa Natural Park] }\end{array}$ & Algarve region \\
\hline $\begin{array}{l}\text { 9. Funchall bay [Madeira } \\
\text { Island] }\end{array}$ & $\begin{array}{l}\text { Funchal urban } \\
\text { area }\end{array}$ \\
\hline 10. Barking Riverside & Thames Gateway \\
\hline $\begin{array}{l}\text { 11. Lower Thames } \\
\text { Crossing }\end{array}$ & Thames Estuary \\
\hline 12. Farlington Marshes & Portsmouth \\
\hline 13. Tipner Regeneration & Portsmouth \\
\hline 14. Palmachim beach & Tel Aviv metropolis \\
\hline $\begin{array}{l}\text { 15. Netanya sandstone } \\
\text { cliffs }\end{array}$ & Tel Aviv metropolis \\
\hline 16. Haifa Port & $\begin{array}{l}\text { Haifa's } \\
\text { metropolitan }\end{array}$ \\
\hline $\begin{array}{l}\text { 17. Managing urban } \\
\text { sprawl }\end{array}$ & Malmö area \\
\hline 18. Falsterbo-Peninsula & $\begin{array}{l}\text { Vellinge, Malmö } \\
\text { area }\end{array}$ \\
\hline 19. Torsviken & Gothenburg \\
\hline
\end{tabular}

\begin{tabular}{l|l} 
Conflict issue & $\begin{array}{l}\text { Category } \\
\text { of Uses }\end{array}$
\end{tabular}

Pollution [air] due to power generation plants, Port and $\quad$ PH, EG infrastructure development and increased human mobility

Delimitation of spatial [definition of] boundary

Coastal area erosion and water shortages due to problematic water use management and waste water drainage

Privatization and anticipated expansion of the airport

Widening of the canal

Expansion of the inland harbour

Tourism lead urban growth threatening the Tagus estuary mouth \& coastline area environment

Tourism, fishing and navigation threatening ecologically sensitive islands

Tourism lead urban waterfront development and increased human mobility

Urban regeneration on scarce brownfield, and housing and employment resources

New Tunnel or Bridge across the lower Thames estuary

NEH

UGD

Protecting wildlife and amenity value from flooding \& erosion

Housing and mixed use urban development in conflict with environmental protection

Development of beach resorts in conflict with environmental protection

Marina \& urban development [housing \& hotels] and coastal defences that are causing further erosion of the cliffs

Extending and developing the port of Haifa versus

competing uses and conservation

Increased human mobility \& clash of planning strategies /

land-use settlement causing environmental stress

Tourism lead urban development and climate change effects on an ecologically sensitive and cultural heritage rich area

Port restructuring and expansion, industrial and urban [housing] development in an ecologically sensitive environment

20. Kungsbacka

Gothenburg area

Wind-power development in an area with rich cultural landscape requiring nature conservation and biodiversity maintenance

21. SGNP [Sanjay
Gandhi National Park]
22. Pallikaranai
Marshland

Mumbai

Urban sprawl, slums and illegal quarrying heavily encroaching the park boundaries reducing its area and diminishing bio-diversity

Chennai

Urban development, garbage dumping \& untreated sewage disposal, marshland area reduced by $90 \%$ and bio-diversity close to extinction

\begin{tabular}{l|l}
\hline $\begin{array}{l}\text { 23. Mangrove forest } \\
\text { 24. Haiphong port }\end{array}$ & Mumbai \\
\hline $\begin{array}{l}\text { 25. Industrial zone } \\
\text { 26. Cat Ba and Nha } \\
\text { Trang }\end{array}$ & Haiphong city \\
\hline
\end{tabular}

Deforestation \& reclamation for housing, industry, slums, sewage treatment and garbage dumps destroying the mangroves

Port up-grade/expansion and logistic services infrastructure occupying wetlands and biodiversity sensitive area

High rate of industrial zone expansion in a context of limited capacity for environmental control \& management

Increased tourism lead infrastructure and urban development in ecologically sensitive environment of islands

UGD

$\mathrm{PH}$

$\mathrm{PH}$

UGD, NEH

NEH, UGD:

NEH, UGD

UGD

UGD, NEH

NEH, UGD

UGD, NEH

UGD

UGD, NEH

$\mathrm{PH}$

UGD

PH, UGD \& NEH

PH, UGD \&

NEH

EG

NEH, UGD

NEH, UGD

NEH, UGD

PH, UGD

PH, UGD

UGD, NEH

From these findings, detailed modelling and classification of conflict types and policy tools will be developed and tested through scenario building and dissemination over the next 18 months. End 
users such as the Environment Agency, Wildlife Trust and Coastal Communities in the UK and their counterparts in partner countries, are engaged on the project through attendance at twice-yearly Partner meetings, commenting on draft reports and analysis of findings, and in critiquing policy and data models arising from our research. It is hoped that SECOA can address and provide practical guidance and tools to the challenges faced in local and regional level coastal and flood risk planning and conflict resolution, and that good practice between partners regions can be exchanged in the future.

\section{References}

DCLG (2010) Planning Policy Statement 25: Development and Flood Risk

Edwards, S.D., Jones, P., Nowell, D.E. (1997) Participation in coastal zone management initiatives review and analysis of examples from the UK, Ocean and Coastal Management, 36(1-3): 143-165 EA (Environment Agency) (2003) Making Space for Water. London EU (2000) Integrated Coastal Zone Management: A Strategy for Europe (COM/00/547).Brussels Timmerman, P. (1996) Coastal Cities in the Context of Global Environmental Change. Toronto 